\title{
Multidimensional analysis of embeddedness and cooperation in a cluster - a literature and empirical study
}

\section{Marzena Frankowska}

\begin{abstract}
Cooperation of enterprises within inter-organizational networks is a complex research and cognitive area due to the multidimensional nature of cooperation, which is often a mixture of motives, intentions, goals and operating conditions. Literature studies have revealed the so far very meager and scattered work in the field of embedding cooperation between enterprises in inter-organizational networks, which definitely does not sufficiently describe the impact of the context of collaboration on enterprise cooperation. The main aim of the article was to understand and explain, on the basis of the concept of embeddedness, whether there are relations between the participation of enterprises in a cluster-type inter-organizational network (embeddedness and its dimensions) and their cooperation in the cluster. Implementation of research goals required the development of a research process covering three stages. The essence and dimensions of embeddedness of cooperating enterprises in inter-organizational networks (structural, relational, social, positional, territorial, geographical, spatial, institutional, ecological, political and temporal) were determined. Next, a survey of European cluster managers (study 1) on cooperation in a cluster was carried out in order to better understand the dimensions of embeddedness of enterprises cooperating in clusters (qualitative research, IDI). In the next stage, a survey of cluster enterprises was carried out (study 2) to determine the relations between their embeddedness in the cluster and cooperation with other cluster companies (quantitative research, CAWI). Then, triangulation of data sources, research methods and context was used. As a result, it was established that four dimensions of embeddedness are of key importance for cooperating enterprises embedded in the cluster, namely: structural, geographical, institutional and relational. Moreover, the results of the research show that there is a positive relation between embedding enterprises in the cluster and their cooperation. Keywords: cluster, network organization, network, embeddedness, cooperation, collaboration, proximity, cluster manager, cluster facilitator
\end{abstract}

1 Marzena Frankowska, Ph.D., Associate Professor, Institute of Management, Department of Logistics, University of Szczecin, 8 Cukrowa St., 71-004 Szczecin, Poland, e-mail: marzena.frankowska@usz.edu.pl (ORCID ID: 0000-0001-6309-0128). 


\section{INTRODUCTION}

Although the issue of cooperation between enterprises has long been present in research on strategic management, nowadays, it is taking on a new dimension. First of all, attention is paid to the multidimensional nature of cooperation, which is often a mixture of motives, intentions, goals, and operating conditions. The difficulty in understanding the nature of the exchange is due to the fact that, more and more often, the partners are not bound by hierarchy or relations based on authorities (Pelletier, Vieru, \& Croteau, 2017). This is particularly relevant to cooperation within inter-organizational networks.

Clusters are an example of network structures in which the cooperation of enterprises aims to obtain benefits primarily from geographical proximity, sectoral concentration, and social factors. Due to the achieved positive effects, a significant increase in interest in cluster and cluster initiatives has been observed for three decades not only in the scientific circles and the enterprise and $R \& D$ sector but also among representatives of higher levels of public management (cluster policy) (Vlados \& Chatzinikolaou, 2019; Gancarczyk \& Bohatkiewicz, 2018).

This dissertation discusses the voluntary membership and functioning of enterprises within a cluster structure on the basis of the concept of embeddedness, which has not yet been well recognized in both a cognitive and research scope. The multidimensionality of embeddedness of interorganizational cooperation, as well as its often paradoxical impact on other research variables, such as effectiveness, competitive advantage, flexibility or innovation, indicates that this is an area requiring in-depth exploration. It can be said that the conceptualization of embeddedness and its operationalization are not fully developed. At the same time, the embeddedness concept has broad applications in many research areas. It is noted that its wider use in economic research could eliminate some of the shortcomings of the analysis, which are characteristic of neoclassical economics (Czernek \& Marszałek, 2015). Economic behavior is embedded in a network of relations that provide context for economic processes (Granovetter, 1985).

Literature studies have revealed the so far very meager and scattered work in the field of embedding cooperation between enterprises in interorganizational networks, which definitely does not sufficiently describe the impact of the context of collaboration on enterprise cooperation (Lis, 2019; Sobolewska, 2020). The conducted studies prove that a research area has been identified that has not yet been extensively explored, a fact which requires undertaking work to strengthen the theoretical and empirical approach. Therefore, two research goals have been defined in the paper: 
- determination of key dimensions of enterprise embeddedness in the cluster;

- examination of the relation between the identified dimensions of enterprise embeddedness in a cluster and cooperation between cluster enterprises.

Implementation of research goals required the development of a research process covering three stages, on which the dissertation structure was based. First, the essence and dimensions of embeddedness of cooperating enterprises in inter-organizational networks were determined based on literature research. Next, a survey of European cluster managers (study 1) on cooperation in a cluster was carried out in order to understand the dimensions of embeddedness of enterprises cooperating in clusters better. In the next stage, a survey of cluster enterprises was carried out (study 2) to determine the relations between their embeddedness in the cluster and cooperation with other cluster companies. The article ends with a discussion on the results of the research presented and conclusions.

\section{LITERATURE REVIEW}

\section{The essence and dimensions of enterprise embeddedness in a cluster}

The need for a broader understanding of the conditions for cooperation of enterprises in clusters finds a number of solutions in the concept of embeddedness. This is a relatively new concept, which was originally introduced by Polanyi in 1944 as part of the broadly understood new economic sociology and later popularized in the works of Granovetter. Nowadays, the concept of embeddedness is understood in multidimensional terms and, hence, its explanation requires comprehensive literature studies.

Granovetter used the concept of embeddedness to explain how social relations affect the economic behavior of entities and transaction conditions. Granovetter (1985) noted that the structure of the network is the result of many interpersonal relations and the individual position of a given entity in the network, as well as how it affects the behavior of other entities. Granovetter (1992) distinguished between structural and relational embeddedness. Structural embeddedness refers to the ownership of the social system and the network of relations as a whole. It describes the impersonal configuration of relations between people and individuals. Whereas, relational embeddedness defines the type of personal relations that develop during interactions between individuals and are reflected in friendship, camaraderie and respect, which translates into the behavior of actors. Embeddedness is expressed in the role of social relations and the 
structure of these relations in building trust and weakening the occurrence of opportunistic behavior. Consequently, it is observed that cooperation with actors of known reputation (known from social relations) is preferable to that with unknown entities.

The concept of embeddedness was eagerly taken up by researchers, as it opened a wide cognitive field in the study of individual aspects of interorganizational cooperation. As noted by Harrison and van Hoek (2010), the shape of inter-organizational relations is always partly determined by the specific properties of the environment in which the partners operate. Individuals and organizations are connected to their environment through diverse direct and indirect relations that form the environment in which economic activity is implemented (Nyholm, 2011).

Today, embeddedness has become a multidimensional concept (Moody \& White, 2003). According to Goodman (2003), embeddedness is a sociomaterial construct and, therefore, it is an ambivalent, conditional, and dynamic concept. It is used in various contexts and its various dimensions are described, as summarized in Table 1.

Table 1. Research on the concept of embeddedness by selected authors

\begin{tabular}{ll}
\hline Author & Dimension of embeddedness \\
\hline Granovetter (1985, 1992) & Structural, relational \\
Gulati and Gargiulo (1999) & Structural, relational, positional \\
Uzzi (1999) & Social \\
Saxenian (1994) & Territorial, cultural \\
Molina-Morales, Capo-Vicedo, and Martínez- & \\
Fernández (2012) & \\
Johannisson, Ramirez-Pasillas, and Karlsson (2002) & Material, structural, institutional \\
Jones, Hesterly, and Borgatti (1997) & Relational, temporal \\
Halinen and Törnroos (1998) & Temporal, spatial as well as political, \\
Nyholm (2011) & technological and market \\
Penker (2006) & Socio-institutional \\
Lebeau and Bennion (2014) & Social, territorial, ecological \\
Xu and Beamon (2006) & Territorial, political, socio-economic \\
\hline Souce: Fratowal
\end{tabular}

Source: Frankowska (2018).

The concept of embeddedness is directly related to enterprise cooperation rooted in inter-organizational networks (network embeddedness) (Martinezdel-Rio \& Cespedes-Lorente, 2014), including clusters. The social network in the cluster is developed by taking various actions and using various means. These networks are supported by both social and geographical proximity, 
as well as enabling the spread of information between cluster entities, thus playing a central role in the development of their competitive abilities (McEvily \& Zaheer, 1999). It should be noted in this respect that embeddedness in social relations is studied at the level of individual actors and is, therefore, a microfoundation for explaining behaviors, processes and their results at organizational and inter-organizational levels (Coleman, 1990; Abell, Felin, \& Foss, 2008). Uzzi (1996) uses the concept of social embeddedness, which he defines as the scope in which commercial transactions are carried out through social relations and networks of relations, which in turn are based on exchanges related to social, non-commercial principles that perform the function of supervisory transaction mechanisms.

Moreover, as the quoted author claims (Uzzi, 1996), the mechanisms of supervision over social embeddedness are revealed prior to the transaction. This approach makes it possible to explain why economic or managerial activities are rooted in social relations, which in turn affect the allocation of managerial activities and the estimation of resources (Stańczyk-Hugiet, 2016). Similarly, Johannisson, Ramirez-Pasillas, and Karlsson (2002) distinguish substantive embeddedness that can be explained as embeddedness expressing a material existence related to the content of social rooting of economic activity. This approach refers to the concept of social capital, which emphasizes the structural dimension of social networks. Actors, depending on how they are embedded in the network, can derive various benefits from the relation network (Chiu \& Lee, 2012).

Embeddedness in a network gives a different perspective on how to evaluate and analyze enterprise collaboration. Gulati and Gargiulo (1999), based on the works of M. Granovetter, developed three dimensions of embeddedness in the inter-organizational network, indicating, apart from structural and relational, also positional embeddedness. According to the researchers, structural embeddedness captures the impact of relations between actors on the possibility of their cooperation. Thus, it determines how the structure of the network affects the propensity and the ability of enterprises to cooperate. The following parameters are examined: extent, density, hierarchy, connections. Furthermore, it is believed that the number of network actors (cluster members) affects the level of embeddedness (Dayasindhu, 2002). According to Johannisson, Ramirez-Pasillas, and Karlsson (2002), structural embeddedness refers to a structure, for example, patterns of personal social relations and social interaction networks or a relational structure and architecture of network ties. It includes direct and indirect linkages as well as weak and strong ones.

As part of relational embeddedness, the impact of social ties on the economic behavior of actors is examined. In this dimension, it is recognized 
that the company is surrounded by other actors with whom it creates an inter-organizational network. Collective social capital that is based on trust and enables access to information permeates this network in a way that promotes or limits the activity of the company (Zaheer, McEvily, \& Perrone, 1998). The benefits of access to information obtained through relational embeddedness are based on the actors' personal ties. Multilateral trust embedded in personal relations also strengthens the close coordination of cooperation of the actors who share the same social capital.

In turn, positional embeddedness allows recognizing the roles of actors in the network (Gulati \& Gargiulo, 1999), as well as the impact of the location of a single actor on their decisions and actions. Structural equivalence is particularly eagerly used as a measure of position, which shows similarities between actors due to their position in the network and centrality, illustrating the extent of the actor's relations with others (Czakon, 2012).

Clusters and cluster initiatives are an inter-organizational network in which enterprises and their value chains are rooted. When conducting their scientific considerations and observations, researchers began to recognize subsequent dimensions of embeddedness that are related to the attributes of clusters and their specificity of operation. One of the most important distinguishing features of clusters is the geographical concentration of enterprises; thus the embeddedness in the region of operation is the subject of much-conducted research.

Saxenian (1994), in her famous work Regional advantage: Culture and competition in Silicon Valley and Route 128, noticed that the ability to build competitive advantage results from territorial embeddedness, which is related to the culture prevailing in the area and the values shared there. The author stated that the success of the Silicon Valley cluster is the result of its embedding in an industrial system that is both decentralized and based on cooperation with dense social networks and a high level of social capital. Halinen and Törnroos (1998) also drew attention to the role of space and geographical location in the operation of the network by considering spatial embeddedness as one of the most important dimensions that should be used to describe the context of a place of interaction. A similar approach was shared by Lebeau and Bennion (2014), who proposed to distinguish territorial embeddedness from structural embeddedness. This type of embeddedness combines the geographical (location), spatial (impact area), and social (culture of the place) dimensions. According to the authors, territorial embeddedness embodies the so-called spatial loyalty towards the actors' place of activity in the network. In other studies, Penker (2006) also pointed to territorial embeddedness. In her opinion, the spatial context comprises the local and territorial dimensions of embeddedness resulting from local practices and methods of operation. 
Whereas, Molina-Morales, Capo-Vicedo, and Martínez-Fernández (2012), in their studies of clusters, distinguished embeddedness in a territory, understood as a sense of belonging to a given community located in a specific geographic space. It comes down to using a homogeneous system of shared common norms and values as well as personal relations as elements conducive to the creation of an "atmosphere of productive activity". This approach refers to the cognitive dimension of the network by Nahapiet and Ghoshal (1998). When carrying out in-depth literature studies, it might be noticed that the effects of territorial embeddedness of the network can be both positive and negative, and the very dimension of embeddedness relates to both the physical distance of actors (geographical proximity) and the location enabling access to specific resources. This approach is developed in work by Cerceau, Mat, and Junqua (2018), who stated that the management of organizational resources is shaped by the context of the territorial embeddedness in which they operate, while the way of resource management shapes the specificity of a given location. The specific approach to resource management resulting from their territorial location, along with the interactions taking place, was called Industrial Ecology, which refers to another ecological dimension of embeddedness described later in the dissertation.

To sum up, geographical embeddedness is not only associated with physical presence in a given area, which is reflected in a reduction in spatial transaction costs, but it also applies to participation in local culture and even tradition, which enables the cognitive coherence of actors in the inter-organizational network and influences their behavior during cooperation. Hence, geographical embeddedness is an important element of cluster research.

When observing the evolution of the cluster concepts, attention is paid to the need for their institutionalization, which is related to the purposeful organization of cluster activity in the form of cluster initiatives. Hence, institutional embeddedness is another dimension recognized by researchers.

Johannisson, Ramirez-Pasillas, and Karlsson (2002) developed the concept of institutional embeddedness in an inter-organizational network, which refers to linkages with economic institutions and social organizations. Researchers operationalized the concept in which they included economic and social institutions at the local level, and provided empirical data on social relations that support the process of local economic development. Van de Ven (1993) also indicates the importance of institutional embeddedness in the context of the study of associations of entrepreneurship and industrial infrastructure, which, according to him, includes:

- institutional solutions aimed at legalizing, regulating and standardizing new technology; 
- public resources of basic scientific knowledge, financing mechanisms and access to competent employees;

- carrying out research and development, production, marketing, and distribution functions by enterprises working for the commercialization of innovation.

The aim of the research was, among others, to determine to what extent the industrial infrastructure identified in this way facilitates or limits entrepreneurship. It was noted that industrial infrastructure does not arise or change immediately by the actions of one or even several key entrepreneurs. Instead, it appears in the course of numerous institutional events, resources and property that co-create each other for a long time, becoming the context of actions undertaken by enterprises. Furthermore, it was established that this type of institutional embeddedness could act as a fictitious force that hinders technological development and adaptation of the enterprise.

In turn, the relational-institutional dimension of embeddedness is proposed by Nyholm (2011), who, in her research, operationalized embeddedness in three orders. The author identified:

- embeddedness in the first order regarding personal relations among cooperating enterprises in a geographically concentrated network;

- embeddedness in the second-order resulting from the membership of persons representing enterprises in local economic and social institutions (e.g., clusters);

- embeddedness in the third-order concerns situations in which economic and social institutions fill gaps in relations between enterprises.

The last order refers to the concept of Burt's structural holes (1992), while the mentioned organizations assume the role of tertius iungens (third who joins) (Obstfeld, 2005). It seems that embeddedness in the third-order illustrates the role of the cluster coordinator. The approach of Nyholm (2011) integrates individual exchange relations as personal ties connecting economic and social activity with the activities of institutions and their role in initiating cooperation between enterprises.

Another described dimension of embeddedness is temporal embeddedness proposed by Halinen and Törnroos (1998). It refers to how enterprises are related in time, i.e. in the past, present, and future. Embeddedness in time can be illustrated by past experience that affects responses, collaboration, and perceptions of the inter-organizational network. As Janasz (2016) notes, the sphere of collective imagination of individual types of organizations formulates their strategies in close connection with their own experiences and past. Expectations for the future have a similar impact, and established relations, to the same extent as experiences, have an impact on decision making as part of the interaction activation process. This 
is in line with the approach of Jones et al., according to whom embeddedness is a continuous process that constantly shapes the relations between various actors of the inter-organizational network (Jones, Hesterly, \& Borgatti, 1997). Thus, embeddedness not only shapes the interaction of actors in the inter-organizational network, but it is also shaped by them. Temporary embeddedness reveals a new perspective and indicates that actors can not only surrender to the context in which they operate (passive attitude), but they can react (reactive attitude), and even take actions actively shaping the nature of embeddedness (active attitude).

Other dimensions of embeddedness were proposed by Lebeau and Bennion (2014), which adds to the complexity of the discussed construct. The researchers distinguished, among others:

- political/policy embeddedness - related to the occurrence of expectations and actions of stakeholders representing and implementing local policy. It may also result from past traditions and future aspirations;

- socio-economical embeddedness - concerns the perception and definition of the role in a social environment. It is also related to one's opinion, including reputation or lack of it. The economic dimension determines the local environmental conditions related to, inter alia, the labor market.

The embeddedness dimensions presented here may have particular significance in the activity of clusters rooted in a public entity, which refers to the typology presented by Markusen (1996). At the same time, they can also apply to large cluster organizations, which, being regionally rooted, pursue national cluster policy goals e.g. go global clusters in Germany, pôle de compétitivité in France (Bembenek, Frankowska, \& Haviernikova, 2016).

As the last presented dimension of embeddedness, it is worth presenting Penker's research (2006), which distinguished, among others, the ecological dimension of the inter-organizational network embeddedness. Ecological embeddedness covers all relations with nature and the local environment, and constitutes the expression of the production and distribution practices, as well as purchasing attitudes used in the area of location. It applies to purchased components, energy savings, and pro-ecological activities.

The described dimensions indicate that embeddedness means participating in a certain imposed narrative in the operating environment. The nature of the narrative can have a positive, negative, or even silent effect, which means that a given inter-organizational network (cluster initiative) is not noticed in the environment. 


\section{The impact of embeddedness in a cluster on its actors}

The presented dimensions of embeddedness confirm the multidimensionality and complexity of this concept, as well as the possibly diverse impact on enterprise collaboration. Embeddedness in a positive aspect enables the acceleration of decision-making, strengthens cooperation and organizational learning, as well as reduces the costs of monitoring cooperation and is a condition for achieving high-level results. It also serves as an effective platform for information exchange and innovation (Uzzi, 1996; 1997). Embeddedness in a cluster can trigger social mechanisms between actors of an inter-organizational network that play a role of coordinating relation security. They include (Jones, Hesterly, \& Borgatti, 1997):

- access restriction, which may result in a limited number of cluster members;

- macroculture, expressed in sharing common values and norms;

- threat of collective sanctions, penalties may be imposed by cluster members for behaviors not accepted by the partners;

- solidifying the reputation of actors, manifesting in the appropriate perception of the skills and reliability of partners in the interorganizational network.

The mentioned mechanisms are ambivalent and, depending on the situation, may constitute factors supporting or limiting the cooperation of enterprises in the cluster (Mitręga \& Zolkiewski, 2012). Researchers note that in some situations, embeddedness in an inter-organizational network can resemble a snare from which it is difficult to break free (Dayasindhu, 2002). The problem may be the desire to legitimize the actions taken, as well as the phenomenon of homophily expressed in greater acceptance for individuals and similar behaviors (Golub \& Jackson, 2012; Kamath \& Cowan, 2015). Social capital, embeddedness and homophily promote collaboration as well as allow sharing culture and strong collective identification (Coleman, 1990), but they can also maintain rigid relations and redundancy of information. An example is a study of Martinez-del-Rio and Cespedes-Lorente (2014) regarding the dissemination of environmental practices in clusters. Cluster members with a higher level of network embeddedness are more pressured to achieve environmental responsibility, which is due to the following premises:

- they perceive the moral and cognitive legitimate pressure to take appropriate action as stronger;

- established set of social norms, values and beliefs is more reliable for them within the cluster network;

- there is a fear of losing access to knowledge or other values provided by the cluster if they are sanctioned by other members of the cluster network. 
These statements prompted Uzzi (1997) to formulate the term "paradox of embeddedness." The results of other research on the impact of embeddedness in an inter-organizational network (cluster) on the cooperation of enterprises indicate its various dimensions and effects. Research conducted by Balland, Belso-Martínez, and Morrison (2016) regarding understanding the exchange of informal knowledge proves that structural and social embeddedness has a significant impact on the functioning of the analyzed cluster both in terms of technical knowledge networks and business knowledge networks. As a result, they explain the formation of unformalized knowledge networks because of enterprise embeddedness, their status and distance between enterprises. This is important in acquiring external knowledge resources by cluster inter-organizational network companies. In turn, research conducted by Dayasindhu (2002) regarding a software cluster showed a relation between embeddedness (particularly associated with local culture), knowledge exchange, presence in the cluster and global competitiveness of enterprises. According to the author, territorial embeddedness may be a barrier to the development of cooperation between enterprises in the cluster and their competitive advantage. In the local culture, it is badly received if employees of a company establish relations with other organizations, which is manifested by a reluctance to participate in events promoting knowledge sharing (e.g., symposia, seminars). The author pointed to the need to increase the awareness of the management of enterprises in the cluster in terms of understanding the relation between the level of trust and embeddedness in local culture to strengthen the exchange of knowledge and access to knowledge resources in the cluster. Lin, Huang, Lin, and Hsu (2012) conducted research on clusters where the dominant actors are OEMs (Original Equipment Manufacturer), which, therefore, regard the cooperation of enterprises in supply chains embedded in the cluster. The research took into account the context of relational, structural and positional embeddedness in managing alliances of enterprises cooperating in the cluster. The research results allow for a better understanding of the ways in which formal coordination mechanisms are conditional on embeddedness in a clustered OEM network. First of all, the results show that embeddedness in the network is complementary to the formal mechanisms of coordination of cooperation between enterprises. Secondly, the relation between transaction risk and inter-organizational formal coordination mechanisms may be stronger or weaker depending on the conditions of the network in which enterprises are rooted.

Another study on high tech clusters proves the existence of a relation between structural embeddedness and enterprise collaboration in an inter-organizational network (cluster), which is based on the possibilities of using external cluster effects (Chiu \& Lee, 2012). On the other hand, 
the results of research conducted by Lebeau and Bennion (2014) allowed identifying a cluster anchored in a public entity (universities). Moreover, they drew attention to the multidimensional and sometimes contradictory levels of impact of the entity's embeddedness in the local environment. In another case, Chiffoleau (2009) carried out research on alternative food supply chains in southern France in the context of their embeddedness in the local environment. Alternative supply chains constitute an organized form of supplying local food products to consumers, excluding concentrated retail trade and transnational companies. The study included an analysis of relations between producers as a result of local embeddedness and their relation with the possibility of organizing supply chains in a traditional way. Research results prove that local embeddedness in the relational dimension is a key element of the local production system and coordination of producers' cooperation. A similar view is shared by Nyholm (2011), according to whom the conducted study of assessing the activation of relations in the supply network must take into account the logistics cluster where the surveyed logistics operators are embedded. A very interesting statement was made by Penker (2006), who conducted research on the rooting of food supply chains. She mapped the local network of actors (cluster) involved in food supply chains and in conclusion to the results of the research stated that the question is not "are the supply chains embedded or not?", but should rather be formulated: "where and how are they embedded?."

A review of the cited research shows that there is a relation between embedding in a cluster and the way cluster enterprises operate. At the same time, the test results do not give clear results, as the obtained answers indicate both positive and negative embeddedness as well as paradoxical effects. Moreover, a review of the literature on the subject allows the identification of research and cognitive gap in the form of not specifying those dimensions of embedding enterprises in the cluster that significantly affect the cooperation of cluster actors. Therefore, it will be important to determine which dimensions of embedding actors in a cluster are related to undertaking and developing cooperation between enterprises (regardless of the direction of impact).

\section{METHODOLOGY AND RESEARCH METHODS}

\section{The concept of the research process}

The issue of embedding cooperating enterprises in an inter-organizational network is a complex research area that has not been extensively explored so far. To maintain the rigor of the reliability of the research process in 
management sciences, it is recommended to use many mutually corrective and verifying methods referred to as triangulation (Denzin, 1978; Stańczyk 2018). As a result of the literature research, many dimensions of enterprise embeddedness in a cluster were identified. Thus, further research process was divided into two stages. First of all, it is important to identify which of the embeddedness dimensions are significantly related to the undertaking and development of cooperation by cluster enterprises. In the next step, the relations between the identified dimensions of embeddedness and the cooperation of enterprises in clusters will be analyzed. The assumptions of the research process are presented in Figure 1.

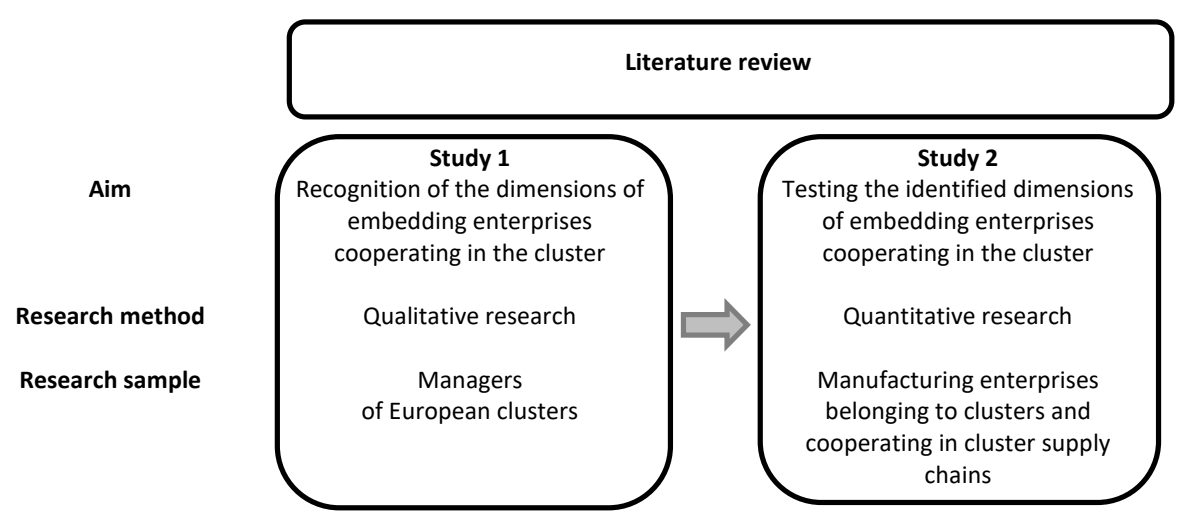

Figure 1. Framework of research methodology

The study included:

- triangulation of data sources at the collective level, consisting in obtaining, using and comparing data from various sources in order to describe a specific phenomenon related to the studied groups (Study 1: cluster managers, Study 2: manufacturing cluster enterprises);

- triangulation of methods regarding the mixing of qualitative (No. 1 test) and quantitative (No. 2 test) methods;

- triangulation of the environment and location, called contextual triangulation, associated with the need to conduct research in various places (study No. 1: European clusters, study No. 2: nationwide study of clusters in Poland). 


\section{Characteristics of empirical research}

\section{Stage 1: Qualitative research}

\section{Research method and description of research sample}

Firstly, introductory and exploratory research was conducted. It was important to recognize the context of the functioning of enterprises in a cluster and the conditions created for their cooperation based on the opinion of cluster managers. The research results indicate that cluster managers play a special role in creating conditions for the cooperation of cluster actors and are a valuable source of knowledge (Ingstrup, 2010, 2013; Frankowska 2019). The aim of the study was, therefore, to fill the identified cognitive and research gap in determining the dimensions of embedding enterprises in the cluster and its impact on the process of cooperation of actors. Therefore, the proposed study took into account the acquisition of knowledge of cluster managers regarding the perception of how clusters operate, the conditions and scope of cooperation in a cluster, as well as the attitudes of cluster enterprises.

The collected research material was analyzed within the following research areas:

- specifics of cooperation between enterprises in a cluster;

- impact of embeddedness in a cluster on enterprise collaboration.

Qualitative research was chosen as the research method, which is used to learn more about and describe complex market phenomena (Strauss \& Corbin, 2008). It allows the exploration of an area that is not fully recognized, which is the cooperation of enterprises in a cluster. The technique applied is in-depth interview (IDI) based on a semi-structured interview (Levitt, Motulsky, Wertz, Morrow, \& Ponterotto, 2017; Gopaldas, 2016). This interview is characterized by the development of a scenario covering important topics to be addressed, as well as non-standardized questions. The researcher formulates them and thus adapts to the course of the conversation. Open questions are gradually specified in more detail (Dudwick, Kuehnast, Jones, \& Woolcock, 2006). Qualitative studies are not representative studies of the entire surveyed population. Therefore, selecting respondents is of key importance in order to obtain the right research material for further reasoning. In this study, the relevant assumptions were adopted for selection and choosing respondents, in order to understand the phenomenon most comprehensively, which is the embeddedness of cooperating enterprises in a cluster (Table 2). 
Table 2. Criteria for selecting respondents for research

\begin{tabular}{|c|c|c|}
\hline \multicolumn{2}{|c|}{ Cluster selection criteria } & \multirow{2}{*}{$\begin{array}{l}\text { Selection aims } \\
\text { Clusters from different EU countries - the international } \\
\text { nature of research }\end{array}$} \\
\hline 1 & Root region & \\
\hline 2 & $\begin{array}{l}\text { The period of functioning } \\
\text { of the cluster organization } \\
\text { and its manager }\end{array}$ & $\begin{array}{l}\text { Clusters in the maturity phase, minimum } 4 \text { years of } \\
\text { operation, which provides the opportunity for the manager } \\
\text { to evaluate cooperation in the cluster in the long term }\end{array}$ \\
\hline 3 & Cluster activity profile & Manufacturing clusters with different sectoral specializations \\
\hline 4 & $\begin{array}{l}\text { Supply chain stage } \\
\text { dominating in the cluster }\end{array}$ & $\begin{array}{l}\text { Clusters representing different stages of the supply chain, } \\
\text { from raw material sourcing to final buyers }\end{array}$ \\
\hline 5 & $\begin{array}{l}\text { Cluster reputation and } \\
\text { scope of activity }\end{array}$ & $\begin{array}{l}\text { Clusters with a recognized reputation on the home market } \\
\text { and active internationally }\end{array}$ \\
\hline 6 & Manager's consent & $\begin{array}{l}\text { Managers who are willing to share knowledge and devote } \\
\text { their time }\end{array}$ \\
\hline
\end{tabular}

To maintain a broad perspective of assessing the cooperation of enterprises in clusters, respondents in the study were managers of European clusters. The characteristics of the studied clusters are presented in Table 3.

Table 3. Characteristics of the studied clusters

\begin{tabular}{|c|c|}
\hline Features & Descriptions \\
\hline Cluster name 1 & CD2E (Création Développement des Eco-Entreprises) \\
\hline Registered office & France, Nord-Pas de Calais \\
\hline Status & Le pôle de compétitivité (accreditation) \\
\hline Sectoral focus & $\begin{array}{l}\text { A cluster of innovative environmental technologies in the field of } \\
\text { ecological waste and pollution treatment, water consumption, the } \\
\text { use of renewable energy sources, responsible use of soil, and eco- } \\
\text { construction and eco-materials. }\end{array}$ \\
\hline $\begin{array}{l}\text { Year of } \\
\text { establishment } \\
\text { and background }\end{array}$ & $\begin{array}{l}\text { A regional initiative in the field of establishing a cluster in } 2000 \text {. The } \\
\text { cluster started operating after two years of preparation, while the } \\
\text { cluster's headquarters in Loos-en-Gohelle was opened in 2004. The idea } \\
\text { of the cluster is to respond to the need for modern and environmentally } \\
\text { responsible reindustrialization of traditional brownfield sites in the } \\
\text { region of northern France (Région Hauts-de-France). }\end{array}$ \\
\hline Cluster name 2 & TRIPLE STEELIX 2.0 \\
\hline Registered office & Sweden, Norra Mellansverige \\
\hline Status & $\begin{array}{l}\text { Incorporated association, } \\
\text { Member of Vanguard Initiative (EU) }\end{array}$ \\
\hline Sectoral focus & Metal-machine and metallurgy cluster \\
\hline $\begin{array}{l}\text { Year of } \\
\text { establishment } \\
\text { and background }\end{array}$ & $\begin{array}{l}\text { The cluster was established in } 2005 \text {, initially as the Swedish Steel } \\
\text { Producers Association Jernkontoret. The name Triple Steelix } 2.0 \text { was } \\
\text { adopted in January } 2015 \text {. The cluster operates as a global centre of } \\
\text { excellence for advanced steel products. }\end{array}$ \\
\hline
\end{tabular}




\begin{tabular}{|c|c|}
\hline Features & Descriptions \\
\hline Cluster name 3 & TRETORGET \\
\hline Registered office & Norway, Hedmark og Oppland \\
\hline Status & Private entity, limited liability company \\
\hline Sectoral focus & Wood cluster \\
\hline $\begin{array}{l}\text { Year of } \\
\text { establishment } \\
\text { and background }\end{array}$ & $\begin{array}{l}\text { The cluster was established in } 2002 \text { on the basis of mapping } \\
\text { commissioned by public authorities. The study showed that this location } \\
\text { had the potential to create a cluster. Initially, it was a political initiative } \\
\text { financed by public funds, however, after about 5-6 years of activity, the } \\
\text { cluster coordinator transformed into a private entity. }\end{array}$ \\
\hline Cluster name 4 & FEMAC (Future Emerging and Modern Agriculture in Catalonia) \\
\hline Registered office & Spain, Catalunya \\
\hline Status & $\begin{array}{l}\text { Bronze Label Certificate awarded by the European Secretariat for Cluster } \\
\text { Analysis (ESCA) for quality management (currently Gold Label) } \\
\text { Association }\end{array}$ \\
\hline Sectoral focus & Agricultural machinery cluster \\
\hline $\begin{array}{l}\text { Year of } \\
\text { establishment } \\
\text { and background }\end{array}$ & $\begin{array}{l}\text { The cluster was established in 1999. Previously, enterprises producing } \\
\text { farming equipment made attempts to cooperate in entering foreign } \\
\text { markets, however, did not achieve significant results. }\end{array}$ \\
\hline Cluster name 5 & VOJVODINA METAL CLUSTER \\
\hline Registered office & Serbia, Vojvodina \\
\hline Status & $\begin{array}{l}\text { Bronze Label Certificate awarded by the European Secretariat for Cluster } \\
\text { Analysis (ESCA) for quality management, } \\
\text { Association }\end{array}$ \\
\hline Sectoral focus & Metal-machine and metallurgy cluster \\
\hline $\begin{array}{l}\text { Year of } \\
\text { establishment } \\
\text { and background }\end{array}$ & $\begin{array}{l}\text { The cluster was initiated in } 2011 \text { by receiving EU funds for the } \\
\text { implementation of a two-year project launching the cluster initiative. It } \\
\text { continues to operate up to this day. }\end{array}$ \\
\hline Cluster name 6 & ŚLĄSKI KLASTER LOTNICZY (Silesian Aviation Cluster) \\
\hline Registered office & Poland, Silesian voivodeship \\
\hline Status & $\begin{array}{l}\text { Key National Cluster (PARP accreditation) } \\
\text { Bronze Label Certificate awarded by the European Secretariat for Cluster } \\
\text { Analysis (ESCA) for quality management (2018) } \\
\text { Association }\end{array}$ \\
\hline Sectoral focus & Aviation industry cluster \\
\hline $\begin{array}{l}\text { Year of } \\
\text { establishment } \\
\text { and background }\end{array}$ & $\begin{array}{l}\text { Initially, Federacja Firm Lotniczych (FFL) was established in the } 1990 \text { s } \\
\text { as a result of the cooperation of } 15 \text { private companies. The cluster was } \\
\text { established in 2006, and since } 2008 \text {, the FFL association has been the } \\
\text { coordinating unit of the cluster. }\end{array}$ \\
\hline
\end{tabular}

Only manufacturing clusters with experience in functioning on the home and international market were selected for the study. Furthermore, the clusters participating in the study by definition were supposed to represent 
various sectoral specializations and stages of the supply chain to ensure the most comprehensive view of the specifics of cooperation between enterprises in clusters (Figure 2).

The previously arranged interviews were carried out during international conferences and brokerage meetings of cluster managers. The interviews lasted about 45 minutes. Each of the interviews was carried out based on a previously prepared scenario and was recorded. In total, six in-depth interviews were conducted.

\section{Study 1: Data analysis and study results}

The analysis of the collected research material, on the one hand, indicates the complexity of the subject matter, and on the other, allows noticing the common elements and some similarity of processes occurring in clusters. The conclusions were formulated both in relation to the specifics of cooperation between enterprises in the cluster and the impact of embeddedness in the cluster on enterprise cooperation.

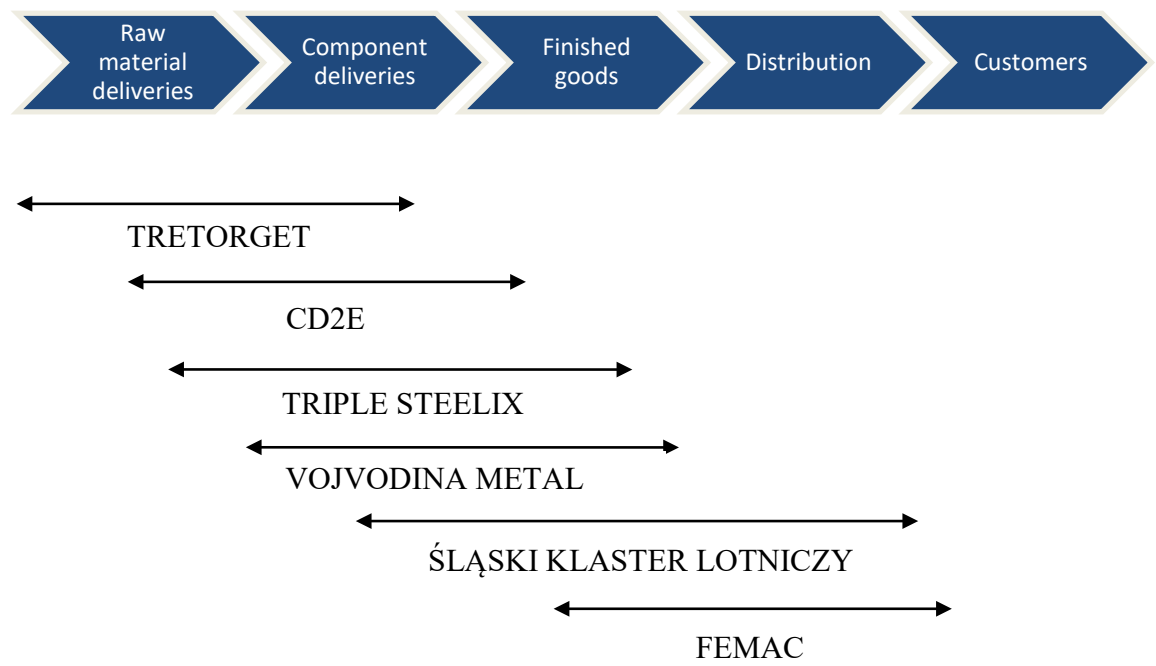

Figure 2. Dominant scope of cluster activity in the supply chain structure

One of the main effects of the study is the disclosure of many barriers in the field of business cooperation. They result from both competitive relations between enterprises (FEMAC, Tretorget, Śląski Klaster Lotniczy, Triple Steelix, Vojvodina Metal Cluster), general distrust and reluctance (Vojvodina Metal 
Cluster, Tretorget), differences in the potential of large and small enterprises (Triple Steelix, CD2E), as well as differences in the ways traditional and modern companies, operate (CD2E). Therefore, the composition of the actors in the cluster and their structure has a significant impact on cooperation. In order to establish cooperation in a cluster, enterprises need:

- time to carefully get used to other enterprises (Femac, Tretorget, Śląski Klaster Lotniczy, Triple Steelix, Vojvodina Metal Cluster, CD2E);

- financial support measures enabling implementation of projects within a cluster (Tretorget, Śląski Klaster Lotniczy, Vojvodina Metal Cluster, CD2E);

- good ideas (projects) for achieving individual economic benefits and a synergy effect (all clusters);

- manager - facilitator who takes into account the individual approach in collective action for the cluster (all clusters).

Interestingly, the study shows the great importance of being embedded in a cluster in shaping the attitude of enterprises in the scope of engaging in cooperation. In the studied clusters, geographical embeddedness that connects the place of activity with local history, tradition and culture, and translates into behavioral aspects of the functioning of enterprises (attitude and applied practices) plays the most important role. In the case of Triple Steelix and Śląski Klaster Lotniczy, the territorial context gives a sense of pride in a region with traditions and significant achievements, as well as motivates to act. However, the situation of the Tretorget and CD2E clusters indicates that territorial embeddedness may resemble a snare from which it is difficult for enterprises to break free, and which becomes an inhibitor in further expansion, limits aspirations, and the ability to cooperate. Moreover, of great importance is political embeddedness, which indicates the role of public actors in the development of the cluster in the sense of applying the appropriate cluster policy, and in the cognitive dimension, i.e. giving importance to specific activities, attitudes, and vision for the development of the cluster in the region. The Triple Steelix cluster and, especially, the $\mathrm{CD} 2 \mathrm{E}$ cluster are examples where the strength and weakness of the region (traditional industry sectors, i.e. mining and shipbuilding) are to acquire an innovative and environmentally-friendly dimension, which starts ventures and introduces a new quality to enterprises.

During the study, temporal embeddedness in the cluster, which describes the changing attitude of enterprises to relations in the past, present and future, was also distinguished. All managers of the studied clusters emphasized the importance of time, which is necessary to develop relations that take up several years of cluster activity. This seems surprising, due to the voluntary membership to the cluster and the lack of coercion into cooperation with 
cluster actors. However, the reasons described and the international selection of clusters indicates that this cannot be accidental. Therefore, according to the observations of the respondents, the phenomenon of coopetition widely described in the literature requires time and is a difficult process in its essence.

As the research findings show, one of the most important types of embeddedness is relational embeddedness, which also indicates this important dimension of the cluster network. The role of managers refers to clusters as a social network. An institutionalized cluster in the form of a cluster initiative, operating through managers in a formalized manner and offering specific services to enterprises, must operate mainly in the relational dimension. The cluster manager, in the course of their tasks, develops relations that enable the creation of social capital in the cluster. This stage is the most difficult and takes the most time. First, the manager creates individual relations between themselves and the companies, and in the next step builds relations between companies. By using neutral activities, creating a space for cooperation, they create social capital in the cluster. Only an appropriate level of social capital makes it possible to start cooperation. It is not owned by either the cluster manager or individual enterprises. It belongs to the actors who make it up, or rather people representing cluster actors. It is worth referring to research indicating that it is individuals (people), not enterprises, or other cluster entities that are real actors in the cluster (Helfer et al., 2014). Thus, the separation of institutional dimension of the cluster (formal participation, payment of contributions, etc.) and the relational dimension, which takes place between individuals, is carried out. The manager performs the function of tertius iungens, i.e. third who joins (Obstfeld, 2005), however, their role is not so much to fill the structural gaps in the information flow system, but rather to integrate subsequent actors into the network of relations on the basis of mediated trust chains. The study reveals a certain mechanism consisting of the need to build a network of relations that provide opportunities to share resources and competences as part of cooperation in a cluster. The study provides empirical grounding for the claim that critical resources may be located outside the enterprise and be embedded in inter-organizational activities and processes, which have been determined by Dyer and Singh (1998) as relational resources.

The role of the cluster manager is also to increase network efficiency through actions balancing the distribution of forces among actors, e.g. strengthening entities with a weaker position in the network structure (SME enterprises, new members), which refers to the dimension of structural embeddedness in the cluster. Activities stimulating cooperation are aimed at overcoming barriers in the cooperation of actors and thus achieving synergistic effects in the form of increasing the efficiency of the functioning 
of individual enterprises and the entire cluster network. On the other hand, they cannot disturb the competition rules in the cluster and the manager's neutral attitude towards the actors of the cluster network.

To sum up, the purpose of qualitative research was to determine the dimensions of embeddedness in a cluster, which have a significant impact on cooperation between cluster enterprises. Based on the collected research material, four embeddedness dimensions, of key importance, were established, i.e.

- geographical embeddedness - determined by belonging to a specific area of a cluster operation;

- structural embeddedness - defining the systems of cooperating enterprises in a cluster;

- institutional embeddedness - indicating the impact of the cluster as an organized cluster structure on enterprises;

- relational embeddedness - illustrating the role of relations and bonds in the cooperation of enterprises in a cluster, as well as in initiating cooperation.

At the same time, it was recognized that although the study indicates the importance of the fifth dimension, which is temporal embeddedness, this dimension is dynamic and will not be included in the No. 2 study that uses quantitative methods (static character). Importantly, research findings indicate significant barriers to initiating business cooperation.

\section{Stage 2: Quantitative research}

\section{Characterization of research method and research sample}

Based on the identified dimensions of enterprise embeddedness in the cluster (study No. 1), the next stage tested the relations between the cooperation of cluster enterprises and the fact of embedding these enterprises in a cluster in accordance with individual dimensions. In order to achieve this, the main hypothesis was formulated:

H1: There is a significant relation between the cooperation of enterprises belonging to clusters and their embeddedness in a cluster.

Next, the main hypothesis was disaggregated into four partial hypotheses, which took the following form:

$H_{a}$ : There is a significant relation between the cooperation of cluster enterprises and their geographical embeddedness in a cluster. 
$H_{\mathrm{b}}$ : There is a significant relation between the cooperation of cluster enterprises and their structural embeddedness in a cluster.

$H_{c}$ : There is a significant relation between the cooperation of cluster enterprises and their institutional embeddedness in a cluster.

$H_{\mathrm{d}}$ : There is a significant relation between the cooperation of cluster enterprises and their relational embeddedness in a cluster.

The study was carried out on a nationwide sample of 135 Polish production enterprises declaring belonging to clusters and simultaneously cooperating in supply chains with other cluster enterprises. The research was performed using a quantitative research method, a standardized questionnaire comprising applied questions with a five-point Likert scale (Dawes, 2008) using a computer-assisted interview (CAWI). The specific study was preceded by a pilot study among 20 companies.

\section{Study 2: Data analysis and study results}

The statistical analysis was carried out in the following order:

- study of existing interdependencies to verify the hypotheses presented in the paper;

- analysis of the distribution of responses in terms of factors favoring and limiting the cooperation of enterprises in the cluster.

\section{Analysis of interdependencies}

Based on study No. 1, the dimensions of embeddedness in a cluster were conceptualized and operationalized. In order to examine the relations between the cooperation of enterprises belonging to clusters and their embeddedness in the cluster, observable variables describing individual dimensions of embeddedness were introduced (Table 4).

The data collected during the research was subjected to in-depth statistical analysis. In order to verify the hypotheses and the dependency analysis (correlation), a significance test was applied on the chi-square statistic values (assuming that the level of significance for a given result will indicate a significant dependence that is $p=0.05$ ) that are a part of the statistical inference, while the strength of such a relation was determined on the basis of Cramér's V, Tschuprow's T and C-Pearson. 
Table 4. Observable variables describing dimensions of embeddedness in a cluster

\begin{tabular}{|c|c|c|}
\hline $\begin{array}{l}\text { Embeddedness } \\
\text { dimension }\end{array}$ & Symbol & Independent variables \\
\hline $\begin{array}{l}\text { Geographical } \\
\text { embeddedness }\end{array}$ & GEO1 & Cluster actors are located close enough to each other \\
\hline \multirow{2}{*}{$\begin{array}{l}\text { Structural } \\
\text { embeddedness }\end{array}$} & STR1 & The cluster has the right number of actors \\
\hline & STR2 & The cluster includes the right actors \\
\hline \multirow[t]{3}{*}{$\begin{array}{l}\text { Institutional } \\
\text { embeddedness }\end{array}$} & INS1 & $\begin{array}{l}\text { Participation in the cluster is based on formal principles } \\
\text { (contract, bylaw, regulations, declaration, etc.) }\end{array}$ \\
\hline & INS2 & $\begin{array}{l}\text { In the cluster, the goals and/or strategy are properly } \\
\text { defined and well known }\end{array}$ \\
\hline & INS3 & The coordinator performs their duties well \\
\hline \multirow{3}{*}{$\begin{array}{l}\text { Relational } \\
\text { embeddedness }\end{array}$} & REL1 & Communication between cluster actors is sufficient \\
\hline & REL2 & $\begin{array}{l}\text { The coordinator helps build good relations and trust } \\
\text { among cluster actors }\end{array}$ \\
\hline & REL3 & $\begin{array}{l}\text { Cooperation of the cluster companies is based on personal } \\
\text { contacts }\end{array}$ \\
\hline
\end{tabular}

Determining the degree of dependence strength resulting from the value of the correlation coefficient is not clearly normalized. This dissertation adopts the interpretation in accordance with Table 5.

Table 5. Interpretation of correlation coefficient values

\begin{tabular}{ll}
\hline Correlation coefficient value & Strength of linkages between variables \\
\hline $0-0.2$ & weak \\
$0.2-0.4$ & moderate \\
$0.4-0.6$ & average \\
$0.6-0.8$ & strong \\
$0.8-1.0$ & very strong \\
\hline Source: Czyżycki, Hundert, \& Klóska (2006, p.157). &
\end{tabular}

In extreme cases, if the value of the correlation coefficient is 0 , it means a complete lack of linkage, and when it is 1, it means full linkage. Table 6 presents the study on the correlation between the observable variables (independent variables) and the interaction of cluster members with other cluster enterprises (independent variable). 
Table 6. Analysis of the relations between dimension of embeddedness in a cluster and cooperation of cluster enterprises

\begin{tabular}{lllll}
\hline Embeddedness dimension & p-value & Tschuprow's T & Cramér's V & C-Pearson \\
\hline GEO1 & 0.00061 & 0.27461 & 0.27461 & 0.48139 \\
STR1 & 0.000039 & 0.29974 & 0.29974 & 0.51417 \\
STR2 & 0.021287 & 0.22585 & 0.24269 & 0.38751 \\
INS1 & 0.000009 & 0.31097 & 0.33416 & 0.50093 \\
INS2 & 0.003816 & 0.25505 & 0.25505 & 0.4544 \\
INS3 & 0.00002 & 0.30557 & 0.30557 & 0.52146 \\
REL1 & 0.000746 & 0.27259 & 0.27259 & 0.47867 \\
REL2 & 0.011641 & 0.24148 & 0.24148 & 0.4349 \\
REL3 & 0.000502 & 0.27653 & 0.27653 & 0.48398 \\
\hline
\end{tabular}

It should be noted that various correlation coefficients based on chisquare statistics (Bergsma 2013; Wijayatunga, 2016) are used interchangeably in the literature. Therefore, for comparison purposes, Table 6 uses the correlation coefficients listed (Cramér's V, Tschuprow's T and C-Pearson). However, in the rest of the dissertation, the reasoning will refer only to the C-Pearson's coefficient.

The analysis of the research results indicates that there is a significant relation with average strength between all independent variables (dimensions of enterprise embeddedness in the cluster) and the dependent variable (cooperation of enterprises). The exception is the STR2 variable, where there is a significant relation, however, of moderate strength. Thus, all partial hypotheses were maintained. As a consequence, the main hypothesis was also confirmed, according to which there is a relation between embedding enterprises in a cluster and them deciding to cooperate.

\section{Factors favoring and limiting cooperation in a cluster - analysis of the distribution of answer structure}

The primary goal of cluster organizations is to create conditions for cooperation of its actors. The belonging and functioning of enterprises within-cluster organizations are associated with subjective expectation of benefits. Hence, in the course of research, the conditions for cooperation in the cluster were assessed, which required identification of factors favoring and limiting cooperation. Respondents were asked about the reasons for cooperation in the cluster. They pointed out the importance of individual factors in undertaking and developing cooperation with cluster entities, as shown in Figure 3. 


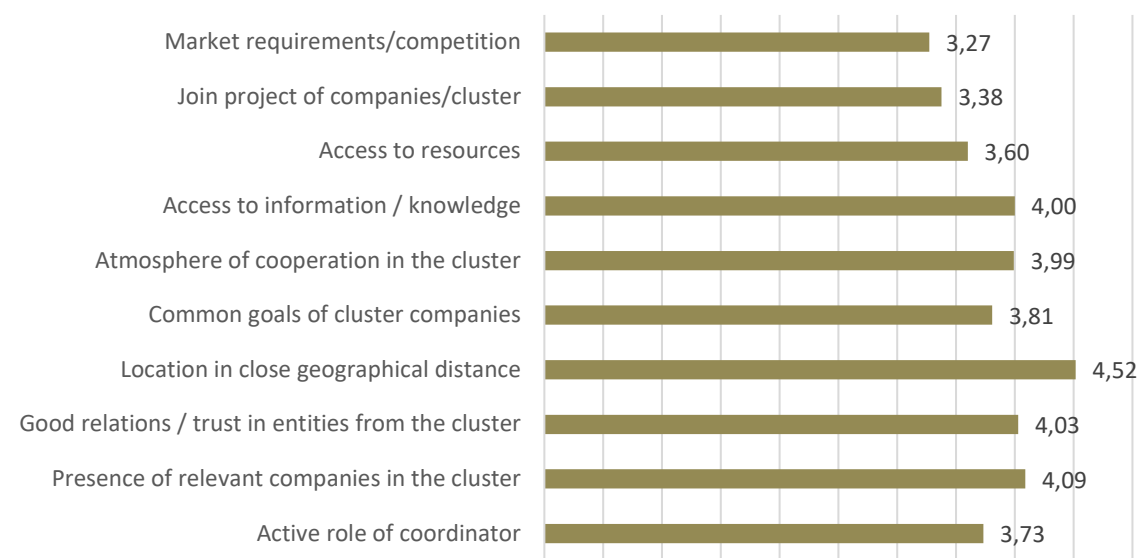

Figure 3. Average assessment of the importance of reasons for cooperation between cluster actors

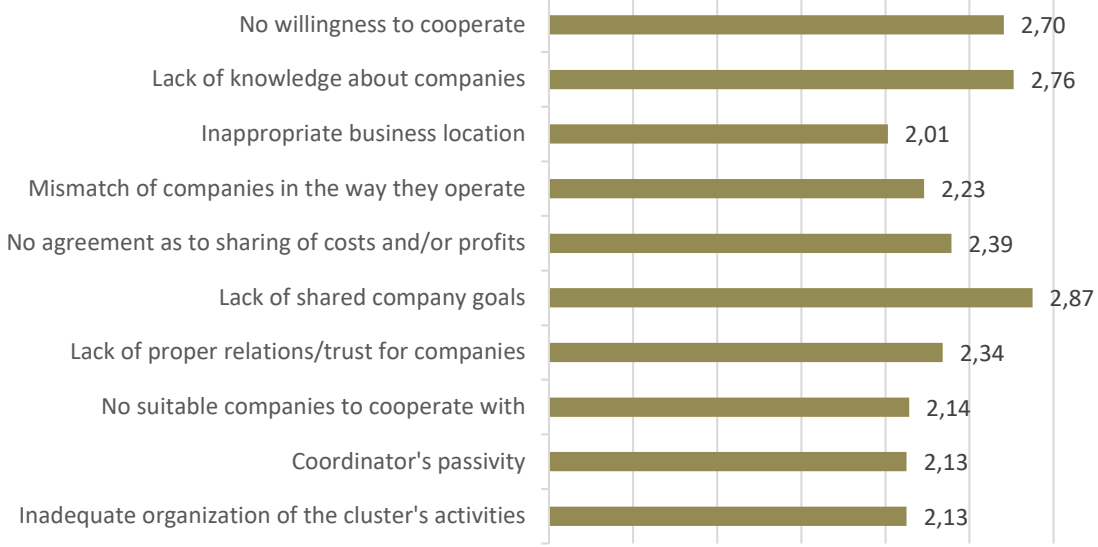

Figure 4. Average assessment of the importance of barriers limiting cooperation in a cluster

Analysis of the research results (Figure 3 ) proves that the main reasons for cooperating in a cluster are the geographical proximity (4.52) of enterprises with an appropriate manner and scope of activity (4.09), that is characterized by good relations and trust (4.03), an atmosphere of cooperation (3.99), and sharing of knowledge between enterprises (4.00). The convergence of the goals of cluster enterprises (3.81), as well as the active role of the cluster 
coordinator (3.73), is also important. At the same time, it turns out that protection against competition is a relatively weak factor motivating the cooperation of companies, just like a joint cluster project. In the latter case, the reason may be limited funding for cluster projects among the studied clusters (Frankowska, Myszak, \& Jedliński, 2016).

However, a cluster, as a cooperation-oriented organization, may, as a result of improper functioning and management, limit cooperation or not fully create opportunities for cooperation. Hence, the respondents were also asked to assess the barriers to cooperation occurring in the cluster (Figure 4). The analysis of average assessments of the importance of individual barriers limiting cooperation in a cluster proves that the barriers occur to a relatively small extent. Among the factors inhibiting cooperation, one may indicate the lack of common goals of companies (2.87) or their unwillingness to cooperate (2.70). They should be included in the internal conditions of enterprises, which may, however, be caused by factors related to territorial embeddedness, which refers to the culture and customs prevailing in the area of cluster operation. The barrier that can be overcome is the lack of knowledge about enterprises in the cluster and poor familiarity of them (2.76), which in turn is related to the job of cluster managers.

\section{ANALYSIS AND DISCUSSION OF THE RESULTS}

Research on embedding cooperating enterprises in a cluster is a complex issue. Therefore, it should be investigated based on methodological pluralism, which is presented in Table 7 . In the research process, an attempt was made to find the truth by identifying relations of enterprise embeddedness in clusters with their cooperation. This became the main objective of the research carried out by both European cluster managers and the cluster enterprises themselves.

The research allowed making the following findings. First of all, the relation between the company's membership in the cluster (embeddedness in the cluster) and cooperation between cluster actors was confirmed. The survey of cluster managers enabled the identification of the main dimensions of embeddedness related to the cooperation of companies.

Four dimensions of embeddedness in the cluster were adopted, which include:

1) Geographical embeddedness, which is determined by belonging to a specific area of cluster operation.

2) Structural embeddedness, which defines the system of cooperating enterprises in the cluster. 
Table 7. The scope of methodological triangulation used in the research process

\begin{tabular}{lll}
\hline Triangulation & Study 1 & Study 2 \\
\hline Data sources & $\begin{array}{l}\text { Research on European cluster } \\
\text { managers }\end{array}$ & $\begin{array}{l}\text { Research on enterprises } \\
\text { belonging to clusters }\end{array}$ \\
Research methods & $\begin{array}{l}\text { Qualitative research - in- } \\
\text { depth direct interviews (IDI) }\end{array}$ & $\begin{array}{l}\text { Quantitative research } \\
\text { - on a representative } \\
\text { nationwide research sample } \\
\text { (CAWI) }\end{array}$ \\
& & National enterprises \\
\hline
\end{tabular}

3) Institutional embeddedness, which illustrates the impact of the cluster as an organized structure on cluster enterprises and their cooperation.

4) Relational embeddedness, which indicates the role of relations and bonds in the cooperation of enterprises in the cluster, as well as in initiating their cooperation.

Then, in the next stage of the research process (study of cluster enterprises), the relations between the indicated dimensions of embeddedness in the cluster and the cooperation of cluster enterprises were confirmed (Table 6). Thus, all formulated research hypotheses were upheld.

Creating and stimulating cooperation in a cluster is its primary value (Morgulis-Yakushev \& Solvell, 2017). At the same time, it is a challenge for cluster enterprises, who are often competitors. Therefore, the issue of factors favoring and limiting cooperation constituted a natural background to the research on enterprise embeddedness in the cluster.

Research results, regarding the assessment of the reasons for undertaking cooperation in a cluster, confirm the relations between individual dimensions of embeddedness in the cluster and the cooperation of cluster enterprises (Figure 3). The highest average grade (4.52/5.00) was obtained by the close geographical distance of enterprises (geographical embeddedness). Following that, of key importance were factors connected to relational embeddedness: good relations in the cluster (4.03/5.00), access to information and knowledge (4.00/5.00), as well as the atmosphere of cooperation in the cluster (3.99/5.00). Relatively high average scores were received by factors related to structural embeddedness, which could include: the presence of relevant companies in the cluster (4.09/5.00) and common goals of the cluster companies (3.81/5.00); as well as the factor reflecting institutional embeddedness, which is the active role of a manager (3.73/5.00).

The conducted literature analysis proves the positive, negative, and paradoxical impact of embeddedness in a cluster network. These observations were confirmed in the research of European cluster managers. However, the methods used in quantitative research did not allow for explicit reference 
to these regularities. Moreover, the arrangements regarding the barriers to cooperation in the cluster were not confirmed. Both the literature research and, above all, the research of cluster managers identified clear barriers to cooperation occurring in a cluster. According to the collected research material, they resulted, among others, from geographical embeddedness perceived from the perspective of identity and culture prevailing in the region of the cluster's operation, or from structural embeddedness manifested in differences in the size, potential, and working practices of cluster enterprises. However, the obtained results of barrier assessment by cluster enterprises do not confirm these findings. Analysis of average assessments of the importance of individual barriers limiting cooperation in a cluster proves that the barriers occur to a relatively small extent (Figure 4). On the one hand, it should be recognized that these results are consistent with the average assessments of factors favoring cooperation in the cluster. On the other hand, they were not confirmed in regards to the findings of the cluster managers' research, who pointed to significant barriers to the cooperation of cluster enterprises. Nevertheless, it should be remembered that both the specificity of the studied groups (cluster managers and production companies) and the existing limitations of individual research methods (qualitative and quantitative research) result in the fact that it was not possible to compare fully the research material obtained in the course of two studies. In addition, the survey of managers was dynamic in the sense that it included the time perspective of the cluster organization. Thus, the opinions of the respondents included the entire cooperation process from the moment of initiation to the subsequent stages of its development. In turn, cluster enterprise surveys are static and present an assessment of the interviews being carried out at a given moment.

\section{CONCLUSIONS}

The main aim of the article was to understand and explain, based on the concept of embeddedness, whether there are relations between the participation of enterprises in a cluster-type inter-organizational network (embeddedness and its dimensions) and their cooperation in the cluster. In order to successfully implement such a task, it was necessary to conduct extensive literature studies and conduct in-depth empirical research.

Literature research allowed exploring the concept of embeddedness and identified its various dimensions. The following types of embeddedness were described: structural, relational, social, positional, territorial, geographical, spatial, institutional, ecological, political, and temporal. This, in turn, allowed conducting empirical research. In the first place (study 1 ), in-depth interviews 
(IDI) with managers of European clusters (France, Spain, Norway, Serbia, Sweden, Poland) representing organizations in maturity and covering all stages of the value chain (upstream and downstream supply chain) were carried out. Research material was obtained, allowing addressing identified research problems, which include:

- recognition of the mechanism of cooperation of enterprises in the cluster;

- observing the relation of embeddedness in a cluster with cooperation of enterprises.

As a result, it was established that four dimensions of embeddedness are of key importance for cooperating enterprises embedded in the cluster, namely: structural, geographical, institutional and relational. Thus, the identified cognitive gap was filled, and the first research goal was achieved. The above-mentioned findings required further in-depth research. Hence, the second of the research objectives set out was the necessity to verify empirically the relations of embeddedness in the cluster with the cooperation of enterprises. In accordance with the postulate to maintain methodological rigor and verify methods (triangulation), research was continued using a different method and a different data source. Thus, study 2 used quantitative methods (CAWI) and it was carried out among production enterprises belonging to clusters. The results of the research maintained all partial hypotheses. As a consequence, the main hypothesis was confirmed, according to which there is a positive relation between the embeddedness of enterprises in the cluster and their cooperation.

The conducted literature and empirical research (qualitative and quantitative) confirmed that the concept of embeddedness is widely used in management sciences in many research areas. Taking into account interpersonal relations, as well as social, institutional and geographical circumstances of decisions and economic activities, can enrich the analysis, both in the micro- and meso-economic dimensions. It is about a holistic approach and understanding the embeddedness of cooperating companies in the network, which will allow for a more effective search for ways to gain competitive advantage. At the same time, one should be careful not to oversocialize approaches regarding shaping behavior in economic relations (Nyholm, 2011). As Uzzi (1997) underlines, the optimal level of embeddedness is a medium-range, which is not too close, so as not to separate relations and lead to their fragmentation, or too loose, so as to allow the formation of relations between actors of the inter-organizational network.

The concept of embeddedness is mainly used to illustrate social complexity and that other contexts of economic activity should not be ignored. It helps better understand the changes and development of inter- 
organizational networks. The value of this dissertation is to confirm the importance of contextual factors (embeddedness in a cluster) for cooperation undertaken in the inter-organizational network, as well as indicate the main dimensions of embeddedness in the cluster related to the cooperative activity of enterprises. In the application dimension, these findings can be of great importance for both cluster managers and decision-makers responsible for shaping cluster policy.

The research presented in the article is not without restrictions. Despite the use of methodological triangulation, it was only possible to partially confront the research material obtained in the course of two studies. This applies in particular to assessing barriers to cooperation between cluster enterprises. Although this was not the main topic of the research undertaken, it seems that this difficult cognitive and research area is related to the ambiguous and even paradoxical impact of embeddedness on the cooperation of enterprises in cluster-type inter-organizational networks. It is, therefore, an area requiring further exploration and research effort.

\section{Acknowledgment}

The project is financed within the framework of the program of the Minister of Science and Higher Education under the name "Regional Excellence Initiative" in the years 2019 - 2022; project number 001/RID/2018/19; the amount of financing PLN 10,684,000.00.

\section{References}

Abell, P.T., Felin, T., \& Foss, N.J. (2008). Building microfoundations for the routines, capabilities, and performance links. Managerial and Decision Economics, 29(6), 489-502. https://doi.org/10.1002/mde.1413

Balland, P.A., Belso-Martínez, J.A., \& Morrison, A. (2016). The dynamics of technical and business knowledge networks in industrial clusters: Embeddedness, status, or proximity?. Economic Geography, 92(1), 3560. https://doi.org/10.1080/00130095.2015.1094370

Bembenek, B., Frankowska, M., \& Havernikova, K. (2016). Cluster policy as a determining factor for development of World Class-Clusters. Humanities and Social Sciences, 23(4), 33-56. https://doi.org/10.7862/ rz.2016.hss.59

Bergsma, W. (2013). A bias-correction for Cramér's $V$ and Tschuprow's T. Journal of the Korean Statistical Society, 42(3), 323-328. https://doi. org/10.1016/j.jkss.2012.10.002

Burt, R.S. (1992). Structural Holes. The Social Structure of Competition. Cambridge, MA: Harvard University Press. 
Cerceau, J., Mat, N., \& Junqua, G. (2018). Territorial embeddedness of natural resource management: A perspective through the implementation of industrial ecology. Geoforum, 89, 29-42. https://doi.org/10.1016/j. geoforum.2018.01.001

Chiffoleau, Y. (2009). From politics to co-operation: The dynamics of embeddedness in alternative food supply chains. Sociologia Ruralis, 49(3), 219-235. https://doi.org/10.1111/j.1467-9523.2009.00491.x

Chiu, Y.T.H. \& Lee, T.L. (2012). Structural embeddedness and innovation performance: Capitalizing on social brokerage in high-tech clusters. Innovation: Management, Policy \& Practice, 14(3), 337-348. https://doi. org/10.5172/impp.2012.14.3.337

Coleman, J.S. (1990). Foundations of Social Theory. Cambridge: Belknap Press of Harvard University Press.

Czakon, W. (2012). Paradoks osadzenia sieci - uwarunkowania metodologiczne. Zarządzanie strategiczne Quo vadis?. Prace Naukowe WWSZiP, 22(2), 237-244.

Czernek, K., \& Marszałek, P. (2015). Koncepcja zakorzenienia społecznego i jej przydatność w badaniach ekonomicznych. Ekonomista, 5, 625-649.

Czyżycki, R., Hundert, M., \& Klóska, R. (2006). Wybrane Zagadnienia ze Statystyki. Szczecin: Economicus.

Denzin, N.K. (1978). Sociological Methods: A Sourcebook (2nd ed.). New York: McGraw-Hill.

Dawes, J. (2008). Do data characteristics change according to the number of scale points used? An experiment using 5-point, 7-point and 10-point scales. International Journal of Market Research, 50(1), 61-77. https:// doi.org/10.1177/147078530805000106

Dayasindhu, N. (2002). Embeddedness, knowledge transfer, industry clusters and global competitiveness: A case study of the Indian software industry. Technovation, 22(9) 551-560. https://doi.org/10.1016/S01664972(01)00098-0

Dudwick, N., Kuehnast, K., Jones, V. N., \& Woolcock, M. (2006). Analyzing Social Capital in Context: A Guide to Using Qualitative Methods and Data. Washington: World Bank Institute.

Dyer, J.H., \& Singh, H. (1998). The relational view: Cooperative strategy and sources of interorganizational competitive advantage. Academy of Management Review, 23(4), 660-679. https://doi.org/10.5465/ amr.1998.1255632

Frankowska, M. (2018). Współdziałanie Przedsiębiorstw w Klastrowych Łańcuchach Dostaw. Warszawa: CeDeWu.

Frankowska, M. (2019). The role of third party cluster managers in strengthening cooperation of cluster companies. Proceedings of the 15th European Conference on Management, Leadership and Governance ECMLG 2019 (pp. 141-149). UK: Academic Conferences and Publishing International Limited, Reading.. https://doi.org/10.34190/MGL.19.068

Frankowska, M., Myszak, J.M., \& Jedliński, M. (2016). Cluster policy report. V4 cluster policies and their influence on the viability of cluster organisations. 
Cluster policy in Poland. Żlin: Visegrad Fund. Retrieved 10 June, 2020, from http://klastr-portal.cz/Resources/Upload/Home/ke-stazeni/v4clusterpol/ v4clusterpol-reports//v4cp_cluster-policy_poland.pdf

Gancarczyk, M., \& Bohatkiewicz, J. (2018). Research streams in cluster upgrading. A Literature review, Journal of Entrepreneurship, Management and Innovation, 14(4), 17-42. https://doi.org/10.7341/20181441

Golub, B., \& Jackson, M.O. (2012). How homophily affects the speed of learning and best response dynamics. Quarterly Journal of Economics, 127(3), 1287-1338. https://doi.org/10.1093/qje/qjs021

Goodman, D. (2003). The quality 'turn' and alternative food practices: Reflections and agenda. Journal of Rural Studies, 19(1), 1-7.

Gopaldas, A. (2016). A Front-to-back guide to writing a qualitative research article. Qualitative Market Research: An International Journal, 19(1), 115-121. https://doi.org/10.1108/QMR-08-2015-0074

Granovetter, M. (1985). Economic action and social structure: The problem of embeddedness. American Journal of Sociology, 91(3), 481-510.

Granovetter, M. (1992). Economic institutions as social constructions: A framework for analysis, Acta Sociologica, 35(1), 3-11. https://doi. org/10.1177/000169939203500101

Gulati, R., \& Gargiulo, M. (1999). Where do interorganizational networks come from?, American Journal of Sociology, 104(5), 1439-1493.

Halinen, A., \& Törnroos, J.Å. (1998). The role of embeddedness in the evolution of business networks. Scandinavian Journal of Management, 14(3), 187-205. https://doi.org/10.1016/S0956-5221(98)80009-2

Harrison, A., \& van Hoek, R. (2008). Logistics Management and Strategy: Competing through the Supply Chain. Harlow: Pearson Education.

Helfer, M., Waldis, S., Drewello, H., Kiehlmann, F., Bouzar, M., HanschHervieux, V., \& Maillier, C. (2014). Résultats de l'atelier international "Management de cluster", Compte rendu de la journée du 14 ai 2014 á Bâle, Document de travail 1/2014, Centre européen de compétences et de recherche Management de Cluster, Université de Strasbourg.

Ingstrup, M.B. (2010). The role of cluster facilitators. International Journal of Globalisation and Small Business, 4(1), 25-40. https://doi.org/10.1504/ IJGSB.2010.035329

Ingstrup, M.B. (2013). Facilitating different types of clusters. Management Revue, 24(2), 133-150. https://doi.org/10.1688/1861-9908_mrev_2013_02_ Ingstrup

Janasz, W. (2016). Wyzwania i dylematy zarządzania współczesnymi organizacjami. In J. Wiśniewska, \& K. Janasz (Eds.), Zarzqdzanie Przedsiębiorstwem Przemysłowym we Współczesnej Gospodarce (pp. 1739). Warszawa: CeDeWu.

Johannisson, B., Ramirez-Pasillas, M., \& Karlsson, G. (2002). The institutional embeddedness of local interfirm networks: A leverage for business creation. Entrepreneurship and Regional Development, 14(4), 297-315. https://doi.org/10.1080/08985620210142020 
Jones, C., Hesterly, W., \& Borgatti, S. (1997). A general theory of network governance: Exchange conditions and social mechanisms. Academy of Management Review, 22(4), 911-945. https://doi.org/10.5465/ amr.1997.9711022109

Kamath, A., \& Cowan, R. (2015). Social cohesion and knowledge diffusion: Understanding the embeddedness-homophily association. SocioEconomic Review, 13(4), 723-746. https://doi.org/10.1093/ser/mwu024

Lebeau, Y., \& Bennion, A. (2014). Forms of embeddedness and discourses of engagement: A case study of universities in their local environment. Studies in Higher Education, 39(2), 278-293. https://doi.org/10.1080/03 075079.2012 .709491

Levitt, H. M., Motulsky, S. L., Wertz, F. J., Morrow, S. L., \& Ponterotto, J. G. (2017). Recommendations for designing and reviewing qualitative research in psychology: Promoting methodological integrity. Qualitative Psychology, 4(1), 2-22. https://doi.org/10.1037/qup0000082

Lin, H.M., Huang, C.H., Lin, C.P., \& Hsu, W.C. (2012). How to manage strategic alliances in OEM-based industrial clusters: network embeddedness and formal governance mechanisms. Industrial Marketing Management, 41(3), 449-459. https://doi.org/10.1016/j.indmarman.2011.04.003

Lis, A. M. (2019). The significance of proximity in cluster initiatives. Competitiveness Review: An International Business Journal, 29(3), 287310. https://doi.org/10.1108/CR-08-2018-0050

Markusen, A. (1996). Sticky places in slippery space: A typology of industrial districts. Economic Geography, 72, 293-313. https://doi. org $/ 10.2307 / 144402$

Martinez-del-Rio, J., \& Cespedes-Lorente, J. (2014). Competitiveness and legitimation: The logic of companies going green in geographical clusters. Journal of Business Ethics, 120(1), 131-147. http://dx.doi.org/10.1007/ s10551-014-2073-3.

McEvily, B., \& Zaheer, A. (1999). Bridging ties: A source of firm heterogeneity in competitive capabilities. Strategic Management Journal, 20, 1133-1156. https://doi.org/10.1002/(SICI)1097-0266(199912)20:12<1133::AIDSMJ74>3.0.CO;2-7

Mitręga, M., \& Zolkiewski, J. (2012). Negative consequences of deep relationships with suppliers: An exploratory study in Poland. Industrial Marketing Management, 41(5), 886-894. https://doi.org/10.1016/j. indmarman.2011.09.023

Molina-Morales, F.X., Capo-Vicedo, J., \& Martínez-Fernández, M.T. (2012). Social capital in industrial districts: Influence of the strength of ties and density of the network on the sense of belonging to the district. Papers in Regional Science, 92(4), 773-790. https://doi.org/10.1111/j.14355957.2012.00463.x

Moody, J., \& White, D.R. (2003). Structural cohesion and embeddedness: A hierarchical concept of social groups. American Sociological Review, 68, 103-127. https://doi.org/10.2307/3088904 
Morgulis-Yakushev, S., \& Solvell, O. (2017). Enhancing dynamism in clusters: A model for evaluating cluster organizations' bridge-building activities across cluster gaps. Competitiveness Review: An International Business Journal, 27(2), 98-112. https://doi.org/10.1108/CR-02-2016-0015

Nahapiet, J., \& Ghoshal, S. (1998). Social capital, intellectual capital and the organizational advantage. Academy of Management Review, 23(2), 242266. https://doi.org/10.5465/amr.1998.533225

Nyholm, M. (2011). Activation of Supply Relationships: A Study of Main Providers in the Turku Logistics Cluster. Åbo: Åbo Akademi University Press.

Obstfeld, D. (2005). Social networks, the tertius iungens orientation, and involvement in innovation. Administrative Science Quarterly, 50(1), 100130. https://doi.org/10.2189/asqu.2005.50.1.100

Pelletier, C., Vieru, D., \& Croteau, A.M. (2017). The interorganizational relationships process: An asset orchestration mechanisms perspective in an SME context. 50th Americas Conference on Information Systems (HICSS) (pp. 5531-5540). Big Island, Hawaii, United States. https://doi. org/10.24251/HICSS.2017.668

Penker, M. (2006). Mapping and measuring the ecological embeddedness of food supply chains. Geoforum, 37(3), 368-379. https://doi.org/10.1016/j. geoforum.2005.09.001

Polanyi, K. (1944). The Great Transformation. The Political and Economic Origins of our Time. Boston: Beacon Press.

Saxenian, A. (1994). Regional Advantage: Culture and Competition in Silicon Valley and Route 128. Boston: Harvard University Press.

Sobolewska, O. (2020). Knowledge-oriented business process management as a catalyst to the existence of network organizations. Journal of Entrepreneurship, Management and Innovation, 16(1), 107-132. https:// doi.org/10.7341/20201614

Stańczyk, S. (2015). Triangulacja - łączenie metod badawczych i urzetelnienie badań. In W. Czakon (Ed.), Podstawy Metodologii Badań w Naukach o Zarzqdzaniu (pp.243-265). Warszawa: Wolters Kluwer.

Stańczyk-Hugiet, E. (2016). Eksplorować czy eksploatować relacje międzyorganizacyjne?, Prace Naukowe Uniwersytetu Ekonomicznego we Wrocławiu, 420, 280-299.

Strauss, A., \& Corbin, J. (2008). Basics of Qualitative Research: Techniques and Procedures for Developing Grounded Theory (3rd ed.). Thousand Oaks, London, New Delhi: SAGE Publications.

Uzzi, B. (1996). The sources and consequences of embeddedness for the economic performance of organizations: The network effect. American Sociological Review, 61, 674-698. https://doi.org/10.2307/2096399

Uzzi, B. (1997). Social structure and competition in interfirm networks: The paradox of embeddedness. Administrative Science Quarterly, 42, 35-67. https://doi.org/10.2307/2393808 
Uzzi, B. (1999). Embeddedness in the market of financial capital: How social relations and networks benefit firms seeking financing. American Sociological Review, 64, 481-505. https://doi.org/10.2307/2657252

Van de Ven, A.H. (1993). The development of an infrastructure for entrepreneurship. Journal of Business Venturing, 8, 211-230. https://doi. org/10.1016/0883-9026(93)90028-4

Vlados, Ch., \& Chatzinikolaou, D. (2019). Business ecosystems policy in Stra. Tech.Man terms: The case of the Eastern Macedonia and Thrace region. Journal of Entrepreneurship, Management and Innovation, 15(3), 163197. https://doi.org/10.7341/20191536

Wijayatunga, P. (2016). A geometric view on Pearson's correlation coefficient and a generalization of it to non-linear dependencies. Ratio Mathematica, 30, 3-21. https://doi.org/10.23755/rm.v30i1.5

Zaheer, A., McEvily, B., \& Perrone, V. (1998). Does trust matter? Exploring the effects of interorganizational and interpersonal trust on performance. Organization Science, 9(2), 141-159. https://doi.org/10.1287/ orsc.9.2.141

Xu, L., \& Beamon, B.M. (2006). Supply chain coordination and cooperation mechanisms: An attribute-based approach. The Journal of Supply Chain Management, 4, 4-12. https://doi.org/10.1111/j.1745493X.2006.04201002.x

\section{Abstrakt}

Współpraca przedsiębiorstw w sieciach międzyorganizacyjnych jest złożonym obszarem badawczym i poznawczym ze względu na wielowymiarowy charakter współpracy, na którq często składaja się motywy, zamiary, cele i warunki działania. Badania literaturowe ujawnity dotychczas bardzo skapq i rozproszonq wiedze w zakresie osadzania wspótpracy przedsiębiorstw w sieciach międzyorganizacyjnych, co zdecydowanie nie odzwierciedla $w$ wystarczajqcym stopniu wpływu kontekstu na współdziałanie przedsiębiorstw. Głównym celem artykułu jest zrozumienie $i$ wyjaśnienie, w oparciu o koncepcję osadzenia, czy istniejq relacje między uczestnictwem przedsiębiorstw w sieci międzyorganizacyjnej typu klaster a współpraca w ramach danej sieci klastrowej. Realizacja celów badawczych wymagała opracowania procesu badawczego obejmujqcego trzy etapy. Określono istotę i wymiary osadzenia współpracujqcych przedsiębiorstw w sieciach międzyorganizacyjnych (strukturalnych, relacyjnych, społecznych, pozycyjnych, terytorialnych, geograficznych, przestrzennych, instytucjonalnych, ekologicznych, politycznych iczasowych). Następnie przeprowadzono wywiady bezpośrednie wśród europejskich menedżerów klastrów (badanie 1) na temat współpracy $w$ klastrze $w$ celu lepszego zrozumienia wymiarów osadzenia przedsiębiorstw współpracujqcych w klastrach (badania jakościowe, IDI). W kolejnym etapie przeprowadzono badanie przedsiębiorstw w klastrze (badanie 2) w celu określenia relacji między ich zakorzenieniem w klastrze a współpraca z innymi firmami klastra (badania ilościowe, CAWI). Następnie zastosowano triangulację źródeł danych, metod badawczych i kontekstu. 
W rezultacie ustalono, że cztery wymiary osadzenia majq kluczowe znaczenie dla przedsiębiorstw współpracujqcych w klastrze. Jest to osadzenie strukturalne, geograficzne, instytucjonalne i relacyjne. Ponadto wyniki badań pokazuja, że istnieje pozytywna zależność pomiędzy włączeniem przedsiębiorstw do klastra a ich współpracq. Słowa kluczowe: klaster, organizacja sieciowa, sieć, osadzenie, współpraca, współdziałanie, bliskość, menedżer klastra, moderator klastra

\section{Biographical note}

Marzena Frankowska is an associate professor at the Logistics Department of the Institute of Management at the University of Szczecin. She is President of the Management Board of the industrial cluster and a manager in international research projects. She is also the author of numerous publications on supply chains, inter-organizational networks, including clusters, as well as the cooperation of manufacturing enterprises and their development.

\section{Conflicts of interest}

The author declares no conflict of interest.

\section{Citation (APA Style)}

Frankowska, M. (2020). Multidimensional analysis of embeddedness and cooperation in a cluster - a literature and empirical study. Journal of Entrepreneurship, Management and Innovation, 16(3), 11-45. https://doi. org/10.7341/20201631 
